\title{
TINJAUAN TIGA DESAIN KAUS KHAS TEGAL
}

\author{
Sudjadi Tjipto Rahardjo ${ }^{1}$, Lintang Woro Hayuningsih ${ }^{2}$ \\ ${ }^{1,2}$ Program Studi Desain Komunikasi Visual \\ Sekolah Tinggi Seni Rupa dan Desain Visi Indonesia, Yogyakarta \\ sudjadi1980@gmail.com ${ }^{1}$, lintang.wh@gmail.com ${ }^{2}$
}

\begin{abstract}
Abstrak
Banyaknya perantau asal Tegal menjadi ide awal bagi produsen kaus di Tegal untuk memproduksi kaus dengan tema khas Tegal yang ditujukan sebagai sarana pelepas rindu kampung halaman. Kaus tersebut juga ditujukan sebagai simbol identitas kedaerahan serta bentuk rasa bangga pada budaya lokal. Penelitian ini mengambil objek tiga desain kaus khas Tegal yaitu Kaus "Galgil", Kaus "Tegal", dan Kaus "Kepriben". Tujuan dari penelitian ini yaitu untuk mengetahui desain kaus khas Tegal jika ditinjau dari penggunaan warna, ilustrasi, tipografi, dan layout serta untuk mengetahui ciri khas dari desain kaus tersebut. Penelitian ini menggunakan pendekatan kualitatif dengan pengumpulan data menggunakan metode observasi dan wawancara. Kemudian metode analisis data yang digunakan adalah analisis data komponensial. Dari hasil penelitian ditemukan fakta bahwa mayoritas konsep desain kaus khas Tegal lebih menonjolkan kata-kata serta istilah dalam bahasa Tegal sehingga desaindesainnya lebih banyak berupa permainan tipografi serta minim penggunaan ilustrasi.
\end{abstract}

Kata Kunci: kaus, Tegal, desain komunikasi visual, identitas lokal

\begin{abstract}
The high numbers of nomans with Tegal origin initiated the idea for the T-shirts producers to design T-shits with particular themes. The T-shirt is also designated as a symbol of a regional identity and a form of pride to the local culture. This research took three Tegal typical T-shirt as the objects namely Galgil Tshirt, Kaus Tegal, and Kepriben T-shirt. The purpose of this research is to know Tegal typical T-shirt design when viewed from the use of colours, illustrations, typography, and layouts, as well as to know the characteristics of the T-shirt design. This research is using qualitative approaches while the source data analized were obtained by observation and interviews. The data analysis method used is componential analysis techniques. The research found fact that the majority of Tegal typical T-shirt design concept are more prominent to words and terms of Tegal languages therefore the designs are more in the form of playing typography and minimal use of illustrations.
\end{abstract}

Keywords: t-shirt, Tegal, visual communication design, local identity 


\section{PENDAHULUAN}

Saat ini di beberapa daerah, dapat ditemui produk-produk kaus lokal yang mengangkat tema kekhasan suatu daerah. Biasanya kaus-kaus tersebut diproduksi dan diperjualbelikan sebagai cinderamata bagi wisatawan, terlebih jika daerah tersebut merupakan daerah tujuan wisata. Manfaat lain fungsi dari kaus tersebut sebagai media untuk mengenalkan budaya dan potensi wisata suatu daerah. Kaus Dagadu (Yogyakarta), kaus CakCuk (Surabaya), kaus Saos (Solo), kaus Melo (Riau), dan kaus Nyenyes (Palembang) merupakan sebagian dari merek-merek kaus yang mengangkat tema kekhasan masing-masing daerah. Menurut Setiawan (2015:64) berdasarkan kajian pada desain kaus oblong Dagadu bahwa Dagadu secara konsisten mengikonkan Yogyakarta dalam setiap desain oblongnya. Ikonik Jogja tersebut muncul pada desain alat transportasi (Andong), kuliner tradisional (Klepon), ikon kota jogja (Tugu), Fashion (Surjan \& Blangkon), serta bangunan heritage cagar budaya (Tamansari). Seperti halnya di daerah-daerah tersebut, Tegal juga memiliki produk-produk kaus yang desainnya mengangkat tema kekhasan Tegal, diantaranya adalah kaus "Galgil", kaus "Jakwir Cetem", "Kaus "Tegal", dan Kaus "Kepriben".

Berbeda halnya dengan kaus Dagadu (Yogyakarta) dan beberapa produk kaus lokal lain yang ditujukan sebagai cinderamata bagi wisatawan, kaus khas Tegal lebih ditujukan bagi masyarakat Tegal khususnya yang merantau ke daerah lain. Hal tersebut dikarenakan Tegal bukan merupakan daerah tujuan wisata seperti Yogyakarta. Namun Tegal merupakan daerah dengan masyarakat yang memiliki karakteristik suka merantau. Oleh karena itu, kaus-kaus khas Tegal lebih ditujukan sebagai media representasi identitas kedaerahan dan juga sarana pelepas rindu kampung halaman.

Desain pada kaus merupakan salah satu bentuk desain komunikasi visual. Desain pada kaus mengandung unsur elemen desain grafis yang terdiri dari gambar (ilustrasi), tipografi, warna, dan layout yang berfungsi sebagai media komunikasi visual. Unsur elemen tersebut merupakan hal yang penting untuk diperhatikan dalam suatu karya desain. Penerapan elemen desain yang tidak sesuai akan berpengaruh pada penerimaan target audiens pada pesan yang ingin disampaikan. Dengan latar belakang tersebut penelitian ini dilakukan. Penelitian akan membahas mengenai desain-desain pada kaus khas Tegal ditinjau dari unsur warna, ilustrasi, tipografi, dan layout yang diterapkan pada media kaus. Selain untuk mengetahui apakah penerapan desain pada kaus khas Tegal sudah sesuai dengan teori DKV, penelitian ini juga bertujuan untuk mengetahui ciri khas dari desain kaus khas Tegal.

Menurut Jumanta (2004:6-7), sejarah kaus bermula sekitar awal abad ke-20 dan penggunaannya hanya sebagai pakaian dalam. Pada tahun 1939 untuk pertama kalinya kaus dicetak sebagai media promosi film "Wizard of Oz". Kemudian di tahun 1950-an kaus mulai populer menjadi pakaian luar berkat acara TV dan film. Ditemukannya teknik cetak saring di atas kaus pada tahun 1960, membuat kaus menjadi populer.

Dikutip dari artikel Perkembangan Kaus di Indonesia (www.medium.com) masuknya kaus di Indonesia dibawa oleh orang-orang Belanda, namun ketika itu 
perkembangannya tidak pesat. Kemudian pada tahun 1970 kaus di Indonesia mulai berkembang pesat dan dikuasai oleh industri kreatif. Muncul merek-merek terkenal seperti "C59" dari Bandung (1980), "Joger" dari Bali (1981), dan juga "Dagadu" dari Yogyakarta (1994). Kemudian di tahun 1990an, di Indonesia mulai marak dengan adanya distro (distribution outlet) clothing dengan kota Bandung sebagai pelopornya.

Suksesnya "Dagadu" yang mengangkat budaya lokal Yogyakarta, membuat para pengusaha kreatif di daerah lain terinspirasi untuk memproduksi kaus yang mengangkat kekhasan masing-masing daerah. Diantaranya kaus "Cak Cuk" dari Surabaya (2005), kaus "Soak Ngalam" dari Malang (2009), kaus "Saos" dari Solo (2010), kaus "Klassik" dari Gresik (2010), dan kaus "Jukut" dari Samarinda (2012). Sementara di Tegal, kaus sejenis mulai muncul sekitar tahun 2009-2011, diantaranya kaus "Umbrus", "kaus Galgil”, dan kaus "Jakwir Cetem".

\section{METODE PENELITIAN}

Metode penelitian yang digunakan pada penelitian ini adalah metode penelitian kualitatif. Model desain penelitian kualitatif menurut Sarwono dan Lubis (2007:95-96) adalah model pernyataan masalah, teknik sampling, jenis data, alat pengumpulan data, metode pengumpulan data, dan teknik analisis. Pernyataan masalah pada penelitian ini adalah bagaimanakah desain kaus khas Tegal jika ditinjau dari penggunaan warna, ilustrasi, tipografi, dan layout, serta bagaimanakah ciri khas dari desain kaus khas Tegal. Sampel desain kaus yang diteliti adalah satu desain kaus dari merek kaus khas Tegal yang sedang populer, yaitu: Kaus "Galgil", Kaus "Tegal”, dan Kaus "Kepriben". Informan yang dipilih adalah desainer dari ketiga produsen kaus tersebut. Jenis data yang digunakan adalah data audio/teks hasil wawancara serta dokumentasi berupa gambar desain kaus.

Pengumpulan data pada penelitian ini menggunakan metode observasi dan wawancara. Observasi dilakukan dengan mengamati desain kaus-kaus khas Tegal, khususnya Kaus "Galgil”, Kaus "Tegal”, dan Kaus "Kepriben". Sedangkan wawancara yg dilakukan terfokus pada hal yang terkait dengan desain kaus, meliputi ide, konsep, dan juga proses pembuatan desain kaus. Teknik analisis yang digunakan adalah teknik analisis komponensial DKV. Menurut Sarwono dan Lubis (2007:114) analisis komponensial menekankan pada kontras atau mengidentifikasi karakteristik yang menunjukkan adanya perbedaan antar elemen dalam suatu domain. Setelah melakukan observasi dan wawancara, kemudian dilakukan pengolahan dan pemilahan data yang terkait langsung dengan tujuan penelitian. Setelah itu dilakukan analisis terhadap elemen warna, ilustrasi, tipografi, dan layout pada desain kaus khas Tegal.

\section{HASIL DAN PEMBAHASAN}

\subsection{Warna, Tipografi, Ilustrasi, dan Layout}

Sebuah karya DKV selalu dilandasi dengan konsep desain, yaitu konsep Tipografi, konsep Ilustrasi, \& konsep Layout. Selain hal tersebut seorang desainer juga menggunakan 'Olah Roso' atau sense of design dalam pembuatan karyanya. Setiawan (2016:113) memaparkan bahwa pencapaian sense of design adalah kemampuan dalam 
mengolah rasa/'roso' dalam perancangan. Aspek kreatif, ekspresi, persepsi, karakter, produktif, inventif, inovasi, dan inspirasi serta emergentif yang keseluruhan hadir dalam konsep perancangan tertuju pada pencapaian nilai estetika. Panca indera dilibatkan pada pemilihan elemen desain yaitu ilustrasi, tipografi, warna, dan layout dalam proses pengerjaan. Rasa dalam perancangan adalah melibatkan diri sepenuhnya untuk mengetahui, memahami, dan menjelaskan sebuah konsep yang nantinya diwujudkan secara konkret dalam perancangan komunikasi visual melalui pemilihan ilustrasi, tipografi, warna, dan layout. Penjiwaan terhadap proses perancangan menjadi bagian upaya mewujudkan kualitas visual yang diinginkan.

Pemilihan warna pada sebuah karya DKV merupakan sebuah unsur penting yang harus disikapi dengan matang. Hal ini selaras dengan penjelasan Anggraini \& Nathalia (2016:37) yang menjelaskan bahwa warna merupakan unsur penting dalam obyek desain. Dengan warna kita dapat menampilkan identitas atau citra yang ingin disampaikan. Baik dalam menyampaikan pesan atau membedakan sifat secara jelas. Warna merupakan salah satu elemen yang dapat menarik perhatian, meningkatkan mood, menggambarkan citra sebuah perusahaan, dan lainnya. Dalam penggunaan warna kita perlu memperhatikan kesan apa yang ingin kita bangun dalam karya desain tersebut.

Pemilihan warna dalam proses perancangan karya DKV berdasarkan faktor budaya si penciptanya Darmaprawira (2002:160) secara garis besar menjelaskan ada dua kelompok warna yang dipergunakan dalam masyarakat Jawa, yaitu kelompok warna sekitar wilayah Yogyakarta dan Solo, serta kelompok warna daerah pesisir sekitar Pekalongan. Untuk kelompok warna di daerah pesisir utara sekitar Pekalongan merupakan susunan warna 'Jawa plus', yaitu memiliki susunan warna yang sama dengan daerah sekitar Yogyakarta dengan tambahan warna yang berasal dari pengaruh luar. Terlihat dari hasil produk batik Pekalongan yang lebih kaya dalam corak maupun warna serta munculnya warna-warna dinamis yang tidak muncul dalam seni batik tradisi Jawa.Dengan letak yang berada di pesisir dan juga berdekatan dengan Pekalongan, susunan warna di Tegal tidak jauh berbeda dengan wilayah Pekalongan, yaitu sama-sama memiliki warna yang kaya dan beragam. Tegal juga memiliki warna khas, yaitu biru untuk wilayah kota Tegal. Sementera hijau muda. untuk wilayah kabupaten Tegal.

Menurut Supriyono (2010:50-51), pengertian ilustrasi secara umum adalah gambar atau foto yang bertujuan menjelaskan teks dan sekaligus menciptakan daya tarik. Ilustrasi yang berhasil menarik perhatian audiens. Pada umumnya harus komunikatif, informatif, dan mudah dipahami. Ilustrasi juga harus memiliki daya pukau (eye catcher) yang kuat serta harus punya kualitas memadai, baik dari aspek seni maupun teknik pengerjaan.

Sementara menurut Sihombing (2015:58), tipografi merupakan representasi visual dari suatu bentuk komunikasi verbal dan merupakan properti visual yang pokok dan efektif. Pada dasarnya huruf memiliki energi yang dapat mengaktifkan gerak mata yang dapat 
dimanfaatkan secara positif apabila penggunaannya senantiasa memperhatikan kaidah-kaidah estetika, kenyamanan, keterbacaan, serta interaksi huruf terhadap ruang dan elemen-elemen visual di sekitarnya. Kenyamanan serta keterbacaan suatu karya tipografi ditentukan oleh legibility dan readability. Sementara dalam simpulannya Isnandar \& Wantoro (2016:33) menegaskan bahwa dalam aplikasi tipografi tingkat legibility, readability dan visibility yang berbeda-beda, pada akhirnya memunculkan kesan visual yang berbeda pula. Pernyataan tersebut dilengkapi oleh penjelasan Rustan (2011:74) bahwa, legibility berhubungan dengan kemudahan mengenali dan membedakan masing-masing huruf/karakter. Suatu jenis huruf dikatakan legible apabila masing-masing huruf mudah dikenali dan dibedakan dengan jelas satu sama lain. Sementara itu readability berhubungan dengan tingkat keterbacaan suatu teks. Teks yang readable berarti keseluruhannya mudah dibaca.

Agar pembaca/audiens dapat mudah menangkap pesan pada suatu desain, diperlukan penataan layout yang baik, yaitu yang sesuai dengan prinsip- prinsip dasar layout. Prinsip dasar layout menurut Rustan (2010:74), antara lain sequence (urutan perhatian), emphasis (penekanan pada elemen penting/utama), balance (keseimbangan pada peletakkan elemen), dan unity (kesatuan dan keterkaitan antar elemen). Sebagai penutup menarik perihal yang dipaparkan Maharsi (2013:111) bahwa huruf memberikan nyawa dalam berkomunikasi, memberikan gestur hidup pada setiap komunikator dalam menjalankan aksinya. Huruf bukan saja mewakili dunia komunikasi, tetapi juga seni estetik yang tervisual dalam media apapun yang sanggup dihampirinya.

\subsection{Kaus Khas Tegal}

Munculnya kaus-kaus khas Tegal bermula dari pencarian identitas kedaerahan yang selama ini kurang dimiliki oleh masyarakat Tegal, khususnya bagi orang Tegal yang berada di perantauan. Mereka yang telah menjadi perantau adakalanya merasa rindu dengan kota kelahiranya. Oleh karena itu keberadaan kaus-kaus bertema kekhasan Tegal ini dapat menjadi sarana pelepas rindu bagi mereka yang ada di perantauan. Tidak hanya itu kaus dengan tema tersebut dapat juga dijadikan sebagai media kampanye budaya Tegal.

Selain tema desain kaus mengenai pulang kampung, kaus khas Tegal juga mengusung tema lain, diantaranya tentang tradisi, kuliner, objek wisata, dan tempat-tempat bersejarah di Tegal. Pada beberapa kesempatan, desain-desain kaus juga menyoroti persoalan-persoalan kekinian, yang diselipi dengan pesan moral. Konsep tema lain, diantaranya tentang wejangan-wejangan hidup dengan bahasa Tegal yang cukup mengena dan guyonan-guyonan khas Tegal.

Dikutip dari blog milik Mulyawan (2012) diketahui bahwa kaus-kaus dengan desain yang mengangkat kekhasan Tegal mulai banyak bermunculan pada kurun waktu 20092011. Salah satu kaus yang muncul pada kurun waktu tersebut adalah kaus "Umbrus" milik salah seorang budayawan Tegal yaitu Haji Tambari Gustam. Konsep desain pada kaus tersebut berupa kata-kata serta plesetan khas Tegal dengan gambar/ilustrasi yang 
minim. Target pasar dari kaus tersebut kalangan menengah ke bawah. Selain itu terdapat juga kaus "Ngresula". Desain kaus ini berasal dari ilustrasi-ilustrasi yang dimuat di koran Radar Tegal, yang kemudian di sablon ke dalam kaus putih ataupun hitam. Kemudian ada juga kaus "Galgil" yang merupakan transformasi dari Tegal Cyber Clothing (salah satu unit usaha Tegal Cyber Community) yang kemudian berdiri sendiri dengan modal yang berasal dari patungan antar anggotanya. Pada kurun waktu yang bersamaan muncul kaus "Jakwir Cetem" milik M. Ersal Aburizal. Sedangkan pada saat ini ada empat merek kaus yang khusus mengangkat tema kekhasan Tegal yaitu kaus "Galgil" (2010), kaus "Jakwir Cetem" (2011), Kaus "Tegal" (2013), dan kaus "Kepriben" (2015).

Penelitian ini berfokus pada tampilan visual desain kaus dari tiga merek kaus khas Tegal yang sedang populer saat ini, yaitu Kaus "Galgil", Kaus "Tegal”, dan Kaus "Kepriben". Dengan sampel desain diambil satu desain kaus dari tiap merek.

\subsection{Analisis Kaus Tegal}

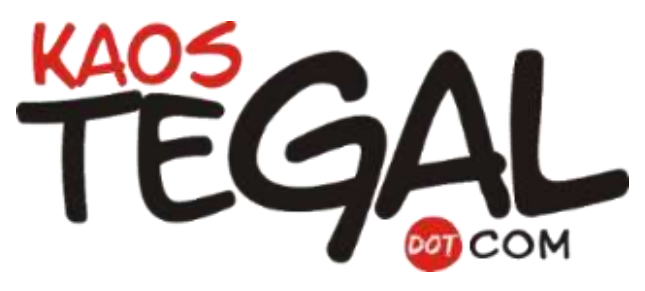

Gambar 1. Logo Kaus Tegal

[Sumber: kaustegal.com. Diakses 9 Mei 2017]

Kaus "Tegal" merupakan salah satu merek kaus bertema khas Tegal yang berdiri sejak tahun 2013. Usaha kaus ini merupakan bisnis keluarga yang dirintis oleh empat bersaudara yaitu Abu Bakar Fahmi, Alimudin Basri, Afzalu Syahrudin, dan Nur Fasikhatun. Berawal dari niat untuk membantu mencukupi kebutuhan orang tua, mereka memilih nama "Kaus Tegal" sebagai merek produknya karena konsep desain kausnya yang mengangkat ciri khas kota Tegal. Semua Visualisasi kaus didesain oleh Afzalu Syahrudin dengan menggunakan software Corel Draw. Ketiga saudara lainnya ikut berperan dalam proses menentukan konsep hingga menjadi desain yang siap cetak.

Dalam produksinya Kaus Tegal hanya dicetak pada bahan kaus dengan warna dasar putih, hitam, dan merah saja. Dikutip dari website Kaus Tegal, pemilihan warna tersebut dikarenakan secara umum warna-warna tersebut dianggap mewakili karakter semangat, kesederhanaan, dan kemewahan. Sementara untuk tema-tema yang diangkat oleh Kaus Tegal yaitu seputar 'bangga dadi wong Tegal' (bangga menjadi orang Tegal), bangga berbahasa 'Ngapak', dan 'ada apa dengan Tegal'.

Dari hasil observasi dan wawancara diketahui bahwa desain-desain Kaus Tegal mayoritas hanya berupa teks dan minim ilustrasi. Dalam hal warna, desain Kaus Tegal lebih umum menggunakan warna merah, hitam, dan putih. Menurut desainernya warna-warna tersebut dianggap netral dan dapat mudah diterima oleh semua 
kalangan. Karena target pasar dari Kaus Tegal adalah semua kalangan (umur/sosial). Selain ketiga warna tersebut, desain Kaus Tegal juga menggunakan warna lain seperti warna kuning, oranye, dan hijau.

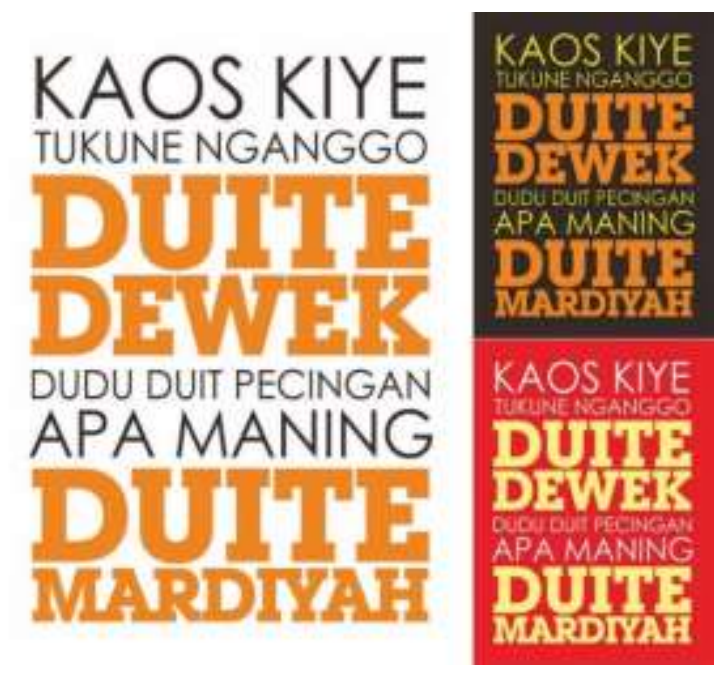

Gambar 2. Desain Kaus Tegal "Kause Dewek"

[Sumber: Dokumentasi Kaus Tegal)

Dalam penelitian ini yang menjadi sampel desain dari Kaus Tegal yaitu desain kaus 'Kause Dewek'. Desain kaus kaus ini bertuliskan 'Kaus kiye tukune nganggo duite dewek, dudu duit pecingan, apa maning duite Mardiyah' yang memiliki arti 'Kaus ini dibeli dengan uang sendiri, bukan uang pemberian orang, apalagi uang Mardiyah'. Menurut desainernya, maksud dari desain ini adalah ingin menekankan kebanggaan bahwa bisa membeli kaus dengan uang sendiri bukan uang pemberian orang. Selain itu desain ini juga ingin mengangkat tokoh 'Mardiyah'. Mardiyah merupakan nama tokoh yang cukup terkenal di Tegal. Dari cerita yang beredar di masyarakat Tegal, Mardiyah merupakan sosok yang paling kaya raya di Tegal pada jaman dahulu. Ada beragam versi dari cerita mengenai Mardiyah. Dikutip dari website www.Infotegal.com cerita mengenai Mardiyah memang benar adanya. la merupakan sosok kaya raya yang memiliki beberapa hotel dan kapal untuk keberangkatan haji. Selain itu ia juga dikenal suka menggunakan perhiasan emas di sekujur tubuhnya dan dikenal dermawan. Dari cerita-cerita mengenai Mardiyah tersebut kemudian muncul istilah 'duite Mardiyah' (uangnya Mardiyah) yang sampai dengan sekarang masih dipakai oleh masyarakat Tegal. Istilah tersebut dipakai saat seseorang tidak memiliki uang, namun ingin membeli sesuatu atau saat dimintai uang oleh orang lain.

Warna yang digunakan pada desain ini hanya berdasar pada selera desainer dan kontras antara warna desain dengan warna dasar kaus. Dalam desain kaus ini warna yang digunakan adalah warna hitam dan oranye untuk kaus dengan warna dasar putih, warna oranye dan kuning untuk kaus dengan warna dasar hitam, serta warna kuning pastel dan putih untuk kaus dengan warna dasar merah. Penggunaan dua warna di sini dimaksudkan agar desain tidak tampak monoton dan juga ingin memberikan penekanan pada beberapa kata penting. Yang pertama yaitu pada kata 'duite dewek' 
(uang sendiri), penekanan pada kata tersebut dimaksudkan untuk menegaskan kebanggaan dapat membeli kaus dengan uang sendiri. Kemudian yang kedua yaitu pada kata 'duite Mardiyah' (uang Mardiyah), yang merupakan salah satu istilah yang sering dipakai oleh masyarakat Tegal saat tidak memiliki uang.

Dalam analisis tipografi, desain kaus ini menggunakan huruf Century Gothic dan LubalGraph Bd BT. Huruf Century Gothic masuk ke dalam jenis huruf sans serif dan memiliki karakter light (tipis). Sementara huruf LubalGraph Bd Bt masuk ke dalam jenis huruf serif dan memiliki karakter bold (tebal). Penggunaan dua jenis huruf dengan karakter yang kontras dimaksudkan untuk memberikan penekanan pada kata 'duite dewek' dan 'duite Mardiyah'. Pada penulisan teksnya, desain kaus ini menerapkan huruf kapital pada semua kalimatnya. Walau begitu teks pada desain ini memiliki tingkat keterbacaan yang cukup karena jumlah teks yang digunakan tidak terkemudian banyak dan menggunakan dua jenis huruf yang memiliki legibility yang tinggi.

Elemen desain yang terdapat pada desain kaus ini hanya terdiri dari unsur teks saja. Pada penataan tata letaknya, teks pada desain kaus ini disusun rata kanan-kiri sehingga membentuk bidang persegi. Kemudian dalam hal ukuran, besar huruf pada teks tiap barisnya juga memiliki ukuran yang berbeda, agar teks tidak terlihat monoton.

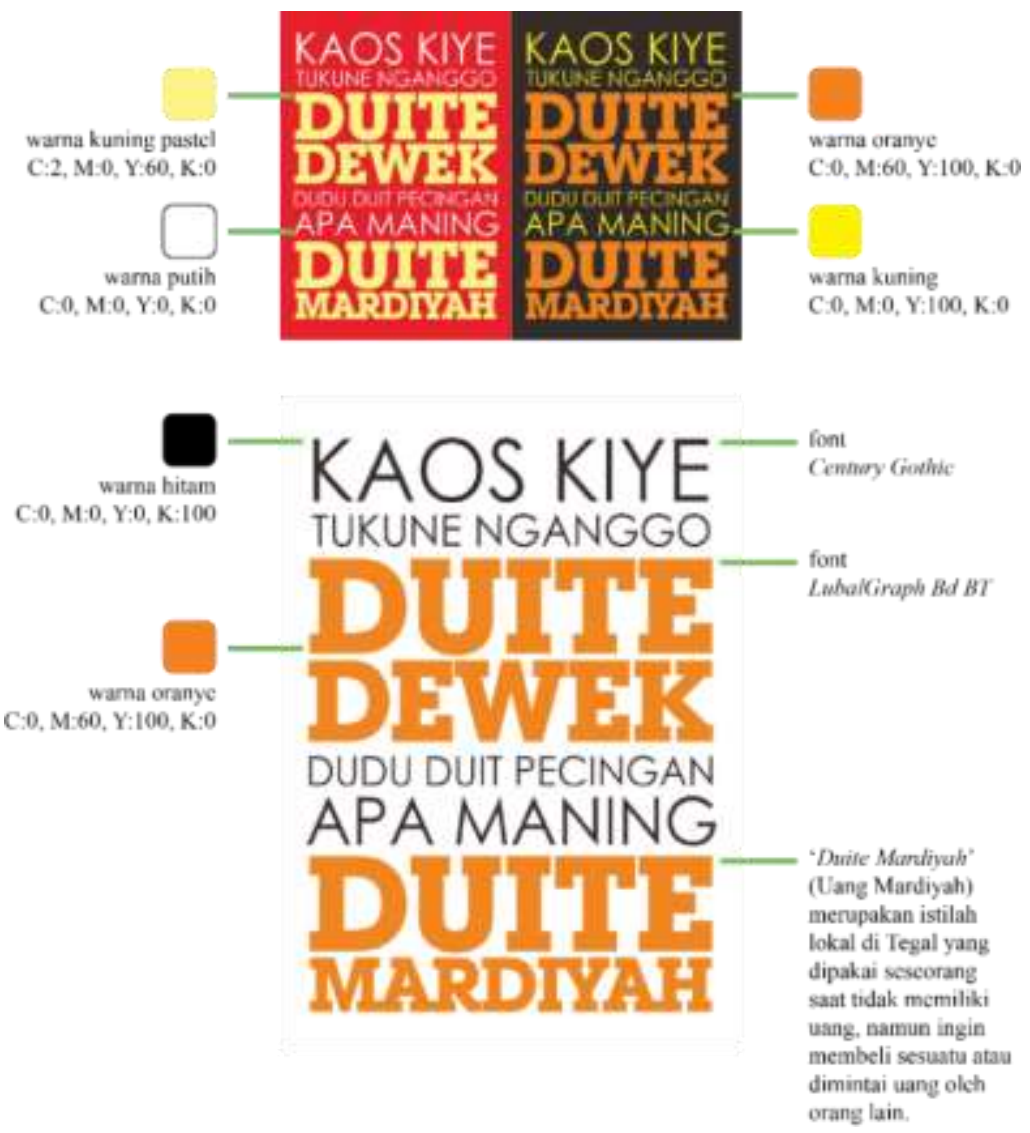

Gambar 3. Bagan analisis desain Kaus Tegal 'Kause Dewek'

[Sumber: Penulis] 
Dilihat secara keseluruhan, desain kaus ini cukup baik. Pilihan warna yang memiliki kontras dengan warna dasar kaus membuat teks menjadi mudah dan jelas terbaca. Selain itu penggunaan dua warna yang berbeda dan penggunaan dua jenis huruf yang memiliki karakter yang kontras dapat memberikan penekanan pada kata-kata yang ingin ditonjolkan. Pada unsur visual yang menunjukkan kekhasan Tegal pada desain kaus, tidak terlihat pada desain kaus. Namun dapat terlihat dari konsep tema/cerita yang diangkat serta pada penggunaan bahasa Tegal.

\subsection{Analisis Kaus Galgil}

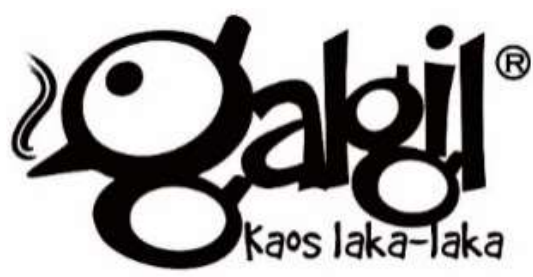

Gambar 4. Logo Kaus Galgil

[Sumber: Dokumentasi Kaus Galgil]

Dikutip dari blog milik Mulyawan (2012), sejarah kaus Galgil bermula dari forum Tegal Cyber Community (TCC) yang merupakan forum komunitas online semacam grup Kaskus namun khusus ditujukan bagi masyarakat Tegal. Kaus Galgil merupakan transformasi dari Tegal Cyber Clothing (salah satu unit usaha Tegal Cyber Community) yang kemudian berdiri sendiri dan berubah namanya menjadi "Galgil" pada Juli 2010. Nama "Galgil" merupakan usulan dari Ahmad Zakiyamini yang artinya: berani dan siap berkelahi bahasa Tegal lain untuk "Galgil" yang mirip adalah "kemlithak, kemaki, angas, petengtang-petengteng, dan petakhilan'.

Desain-desain kaus "Galgil" dirancang oleh Ahmad Zakiyamini dan Indrawan Prasetyo dengan menggunakan software Corel Draw. Tema-tema desainnya bertemakan tentang kearifan lokal, budaya, serta tema-tema ringan yang berhubungan dengan Tegal. Selain tema-tema tersebut, kaus Galgil juga mengangkat tema-tema yang sedang tren di masyarakat.

Dari hasil observasi dan wawancara diketahui bahwa desain-desain Kaus Galgil lebih banyak berupa desain tipografi. Namun beberapa diantaranya terdapat juga ilustrasi. Sementara dalam hal warna, desain Kaus "Galgil" menggunakan beragam warna dan tidak memiliki warna-warna khusus yang ditonjolkan. Hal tersebut dikarenakan Kaus "Galgil" ingin memberikan banyak pilihan warna bagi konsumennya. 


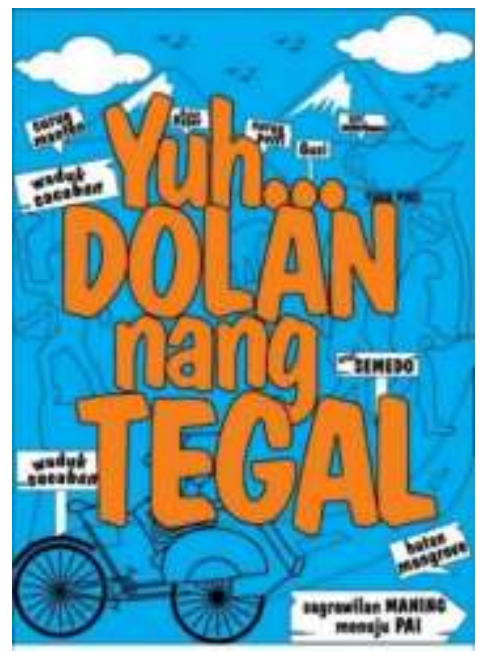

Gambar 5. Desain Kaus Galgil 'Yuh Dolan nang Tegal'

[Sumber: Dokumentasi Kaus Galgil]

Pada penelitian ini yang menjadi sampel desain dari Kaus Galgil yaitu desain kaus Yuh Dolan nang Tegal yang berarti 'Yuk Main (wisata) ke Tegal'. Konsep desain ini yaitu ingin mengangkat serta mengenalkan tempat-tempat wisata yang ada di Kabupaten dan Kota Tegal sekaligus mengajak orang untuk datang ke sana. Objek-objek wisata tersebut adalah Curug Manten, Bukit Baper, Curug Putri, Guci, Guciku Hot Waterboom, Waduk Cacaban, Situs Semedo (situs purbakala), hutan bakau, dan juga PAI (Pantai Alam Indah). Selain tempat wisata, desain ini juga mengangkat dua landmark yang terdapat di Kabupaten Tegal yaitu Tugu Poci dan Patung Obor serta menampilkan juga salah satu jajanan khas Tegal yaitu Tahu Aci.

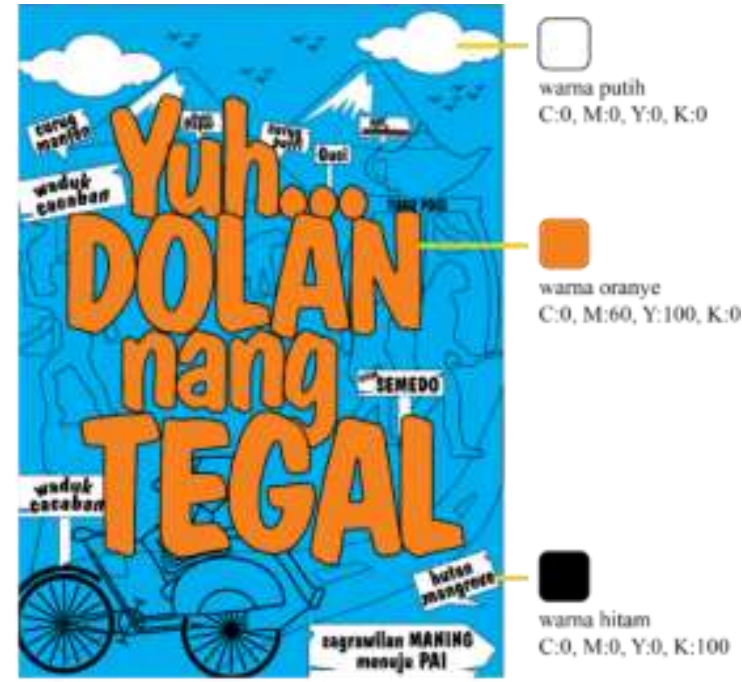

Gambar 6. Bagan penggunaan warna desain Kaus Galgil "Yuh Dolan nang Tegal” [Sumber: Penulis]

Penggunaan warna pada desain kaus ini hanya berdasarkan pada kontras antara desain dan warna dasar kaus. Dalam hal desain warna yang digunakan adalah warna putih, hitam, oranye, dan biru muda sebagai warna bahan kaus itu sendiri. Warna oranye 
digunakan pada teks Yuh... Dolan nang Tegal yang merupakan fokus utama dari desain. Sementara warna hitam dan putih digunakan pada ilustrasi serta teks yang sebagai background. Dalam hal tipografi, desain kaus ini hanya menggunakan satu jenis huruf yaitu Dombold BT. Huruf tersebut memiliki tingkat keterbacaan yang tinggi serta memiliki karakter kasual dan dinamis.

Desain kaus ini memiliki banyak elemen ilustrasi. Ilustrasinya berupa ilustrasi garis (line art). Ilustrasi pada desain kaus ini dibuat sederhana karena hanya ditujukan sebagai latar. Pada bagian paling atas terdapat ilustrasi pemandangan alam berupa gunung, awan, serta burung-burung. Ilustrasi gunung pada desain tersebut menggambarkan wilayah Tegal yang berada di perbukitan yang ada di sekitar area Gunung Slamet di wilayah tersebut terdapat beberapa tempat wisata alam. Pada bagian kanan atas dibawah gunung terdapat ilustrasi Tugu Poci. Tugu Poci merupakan salah satu landmark yang terdapat di Kabupaten Tegal. Pada bagian bawah Tugu Poci terdapat ilustrasi Tahu Aci yang merupakan salah satu jajanan khas Tegal. Selain itu terdapat juga beberapa ilustrasi siluet manusia purba. Ilustrasi tersebut untuk menggambarkan bahwa Tegal juga memiliki situs purbakala yaitu Situs Semedo. Kemudian pada bagian kiri desain terdapat ilustrasi Patung Obor yang juga merupakan salah satu landmark di Kabupaten Tegal. Pada bagian bawah terdapat ilustrasi becak yang merupakan transportasi tradisional yang masih banyak dijumpai di Tegal. Selain ilustrasi-ilustrasi tersebut terdapat juga ilustrasi papan-papan penunjuk jalan yang berisi tulisan nama tempat wisata di Tegal.

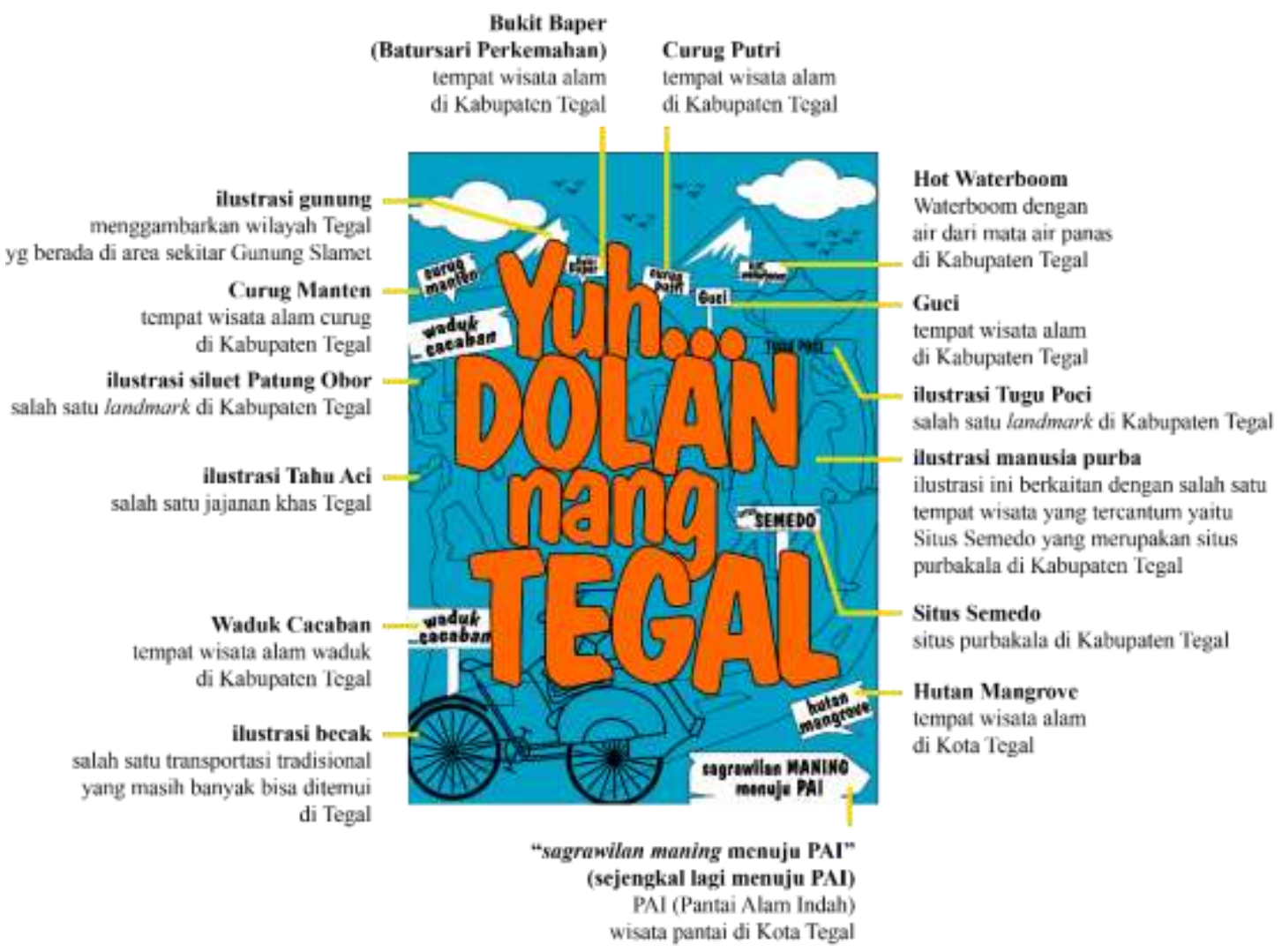

Gambar 7. Bagan ilustrasi desain Kaus Galgil 'Yuh Dolan nang Tegal'

[Sumber: Penulis] 
Elemen desain yang terdapat pada desain kaus ini berupa teks dan ilustrasi garis. Fokus utama dari desain ini adalah teks Yuh... Dolan nang Tegal. Teks tersebut menggunakan huruf dengan karakter tebal, warna yang terang dan kontras. Pada latar terdapat ilustrasi-ilustrasi yang berkaitan dengan tempat wisata, landmark, dan ciri khas Tegal. Terdapat juga ilustrasi papan-papan penunjuk jalan yang bertuliskan nama-nama tempat wisata yang ada di Tegal. Ilustrasi-ilustrasi tersebut dibuat sederhana dan menggunakan warna hitam dan putih.

Secara keseluruhan, tampilan visual desain kaus ini cukup baik. Penggunaan kontras huruf dan warna yang disesuaikan dengan warna dasar kaus membuat desain terlihat jelas. Dalam hal tipografi, huruf yang digunakan memiliki tingkat keterbacaan yang tinggi sehingga teks menjadi mudah terbaca. Kemudian ilustrasi yang digunakan pada desain kaus ini dinilai sesuai dan dapat menggambarkan suasana Tegal. Sementara dalam hal tata letak, susunan elemen pada desain kaus ini terlihat dinamis.

Desain kaus memiliki beberapa elemen visual yang menunjukkan kekhasan Tegal. Diantaranya yaitu bentuk ikon dari Tugu Poci yang memiliki bentuk yang khas dan hanya terdapat di Kabupaten Tegal. Selain itu juga terdapat ikon dari Patung Obor yang juga merupakan salah satu landmark dari Kabupaten Tegal.

\subsection{Analisis Kaus Kepriben}

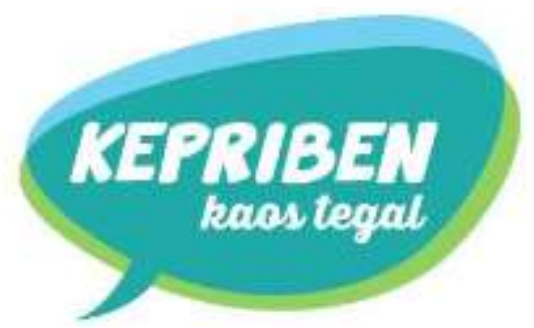

Gambar 8. Logo Kaus Kepriben

[Sumber: www.kaus-kepriben.com. Diakses 11 Juni 2017]

Dikutip dari websitenya, awal lahirnya kaus "kepriben" yang berdiri dari sejak tahun 2015 adalah dari kegelisahan sekaligus keberanian pemilik yang ingin mempromosikan Tegal dan sekitarnya lewat kaus. Alasan memilih kaus sebagai media karena menurutnya kaus cukup mudah untuk digambar, diwarnai dan dituliskan kata-kata sehingga mampu mengkomunikasikan bahwa Tegal memiliki karakter yang unik. Dari kaus tersebut, pemilik ingin mengkampanyekannya dan membangun kesadaran khususnya pada warga Tegal tentang kebanggaannya sebagai warga Tegal.

Dari penuturan pemiliknya, walaupun brand kaus miliknya tergolong baru dan bukan yang pertama kali mengangkat tema khas Tegal, namun tidak berarti brand miliknya hanya ikut-ikutan. Desain dibuat tidak secara asal-asalan. Sebelum melakukan perancangan, konsep yang akan diangkat diulas dan dilakukan brainstorming yang mendalam. Pengerjaan desainnya dilakukan oleh Apit dan Catur sebagai desainer dan konseptor kaus "kepriben". 


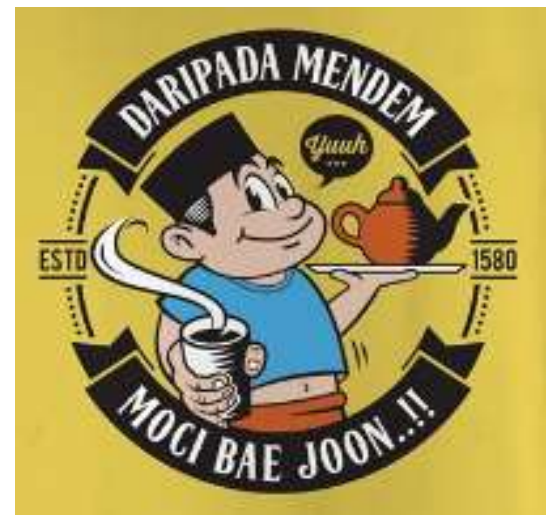

Gambar 9. Desain Kaus Kepriben 'Daripada Mendem, Moci Bae Jon'

[Sumber: Dokumentasi Kaus Kepriben]

Dalam penelitian ini yang menjadi sampel desain dari Kaus Kepriben yaitu desain kaus yang mengangkat tema mengenai teh poci. Menurut desainernya, konsep desain ini yaitu ingin mengangkat serta mengenalkan teh poci yang merupakan minuman khas Tegal. Pada desain kaus ini terdapat kalimat 'Daripada mendem, moci bae Jon!' yang mempunyai maksud 'daripada mabuk lebih baik minum the poci (moci) saja'. Moci pada kalimat tersebut merupakan istilah yang digunakan untuk menyebut aktifitas minum teh yang diseduh dalam poci dan biasanya menggunakan gula batu. Aktifitas minum teh dengan cara ini sudah menjadi kebiasaan dan budaya bagi masyarakat Tegal.

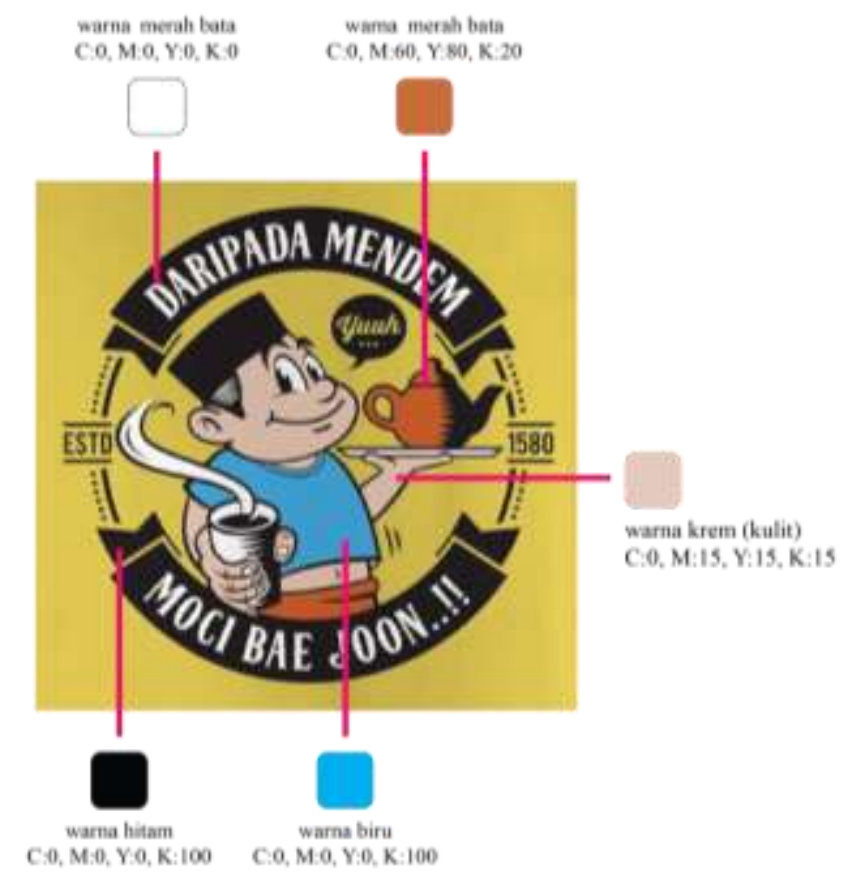

Gambar 10. Bagan penggunaan warna desain Kaus Kepriben "Daripada Mendem, Moci Bae Jon"

[Sumber: Penulis]

Penggunaan warna disesuaikan dengan kontras dari warna dasar kaus sehingga desain dapat terlihat dengan jelas. Dalam desain kaus ini, warna yang digunakan adalah warna 
hitam, putih, biru, krem (warna kulit), merah bata, dan kuning kunyit sebagai warna bahan kaus. Warna merah bata pada desain digunakan pada ilustrasi poci teh yang menunjukkan bahwa poci tersebut terbuat dari tanah liat.

Dalam elemen tipografi, ada tiga jenis huruf yang digunakan pada desain kaus ini. Yang pertama, huruf berjenis dekoratif yang menyerupai huruf K22 Ambelyn Condensed namun memiliki karakter yang lebih tebal yang diterapkan pada teks 'Daripada mendem, moci bae Joon..!'. Kemudian yang kedua, huruf berjenis script yaitu huruf Thirsty Rough Light yang diterapkan pada teks "Yuuh". Dan yang terakhir huruf berjenis sans serif yang menyerupai huruf Bebas yang diterapkan pada teks "ESTD $1580 "$.

Ilustrasi yang terdapat pada desain kaus ini yaitu berupa ilustrasi seorang laki-laki paruh baya yang mengenakan kaus oblong polos berwarna biru, sarung, dan juga peci. Laki-laki tersebut digambarkan sedang membawa nampan yang diatasnya terdapat sebuah poci tanah liat dengan tangan kirinya, sementara tangan kanannya menggenggam gelas berisi teh panas dengan asap yang mengepul. Ilustrasi tersebut menggambarkan ajakan untuk moci atau minum teh dengan poci.

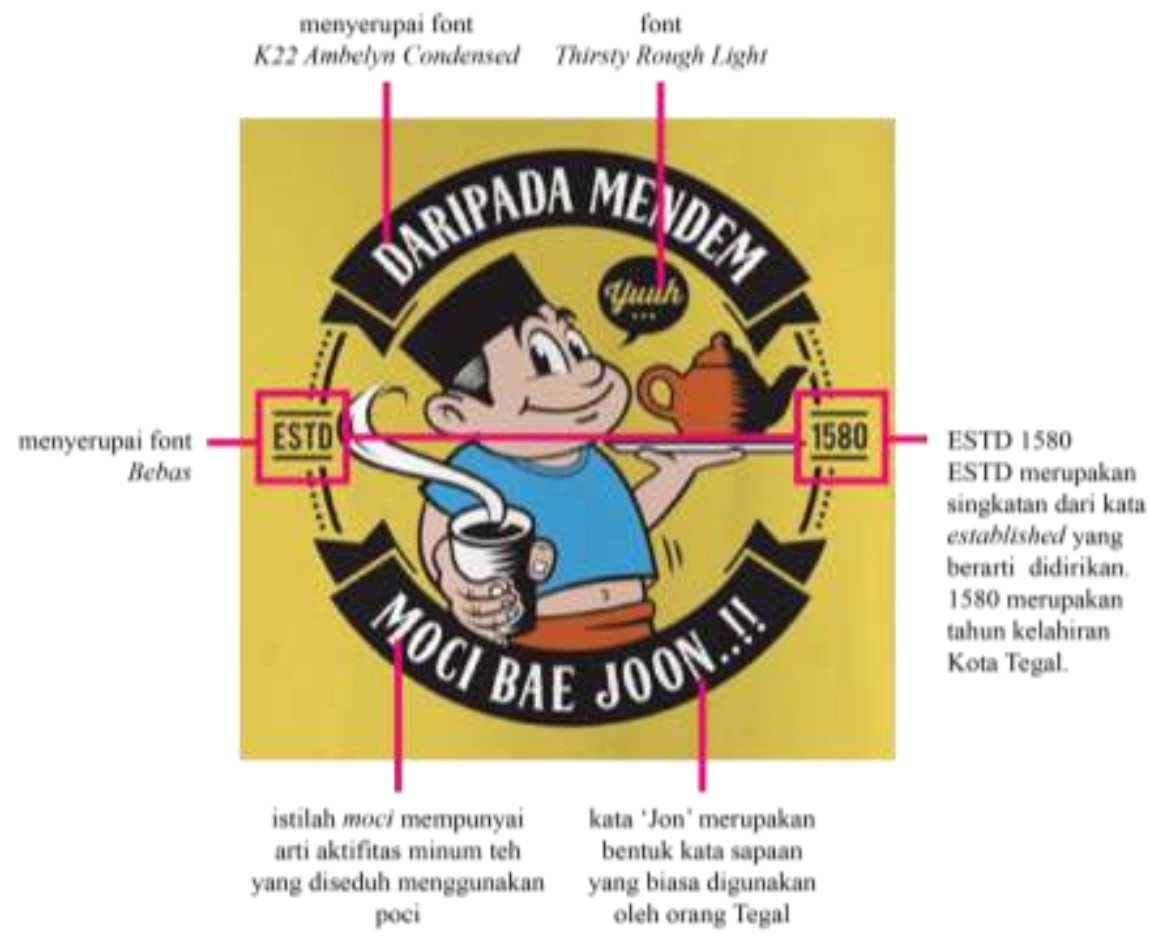

Gambar 11. Bagan tipografi desain Kaus Kepriben 'Daripada Mendem, Moci Bae Jon'

[Sumber: Penulis]

Dari segi tata letak, elemen-elemen pada desain kaus ini disusun membentuk lingkaran dengan elemen ilustrasi yang diletakkan di tengah lingkaran sebagai fokus utamanya. Di samping elemen ilustrasi terdapat balon suara berwarna hitam yang di dalamnya terdapat teks 'Yuuh' (Yuk) yang merupakan kata ajakan. Penulisan kata tersebut menggunakan ruang negatif dengan ikon balon suara sebagai background. Pada bagian 
atas dan bawahnya terdapat teks dengan warna putih yang diletakkan pada dua elemen ribbon banner berwarna hitam. Kedua elemen ribbon banner tersebut dibentuk mengikuti alur lingkaran. Sementara pada bagian kanan dan kiri elemen ilustrasi, terdapat teks 'ESTD' dan '1580'. 'ESTD' merupakan singkatan dari kata established yang memiliki arti didirikan. Singkatan tersebut biasanya terdapat pada desain kaus untuk memberikan keterangan tahun berdirinya brand kaus tersebut. Namun pada desain kaus ini singkatan tersebut diikuti dengan angka 1580 yang merujuk pada tahun lahirnya kota Tegal.

Secara keseluruhan tampilan visual desain kaus ini cukup baik. Penggunaan warna sesuai dengan konsep yang kaus itu sendiri. Selain itu warna yang digunakan juga memiliki kontras dengan warna dasar kaus. Huruf yang digunakan pada teksnya juga memiliki tingkat keterbacaan yang tinggi sehingga desain terlihat jelas dan mudah terbaca. llustrasi yang digunakan juga sesuai dan dapat memberikan kesan ajakan untuk moci yang merupakan suatu kebiasaan/budaya yang biasa dilakukan oleh masyarakat Tegal.

Untuk unsur yang menunjukkan kekhasan Tegal pada desain kaus ini tidak hanya terlihat pada teksnya yang menggunakan bahasa Tegal. Namun juga terlihat pada ilustrasi poci teh pada desain yang bentuk dan warnanya sesuai dengan poci teh yang biasa digunakan di Tegal.

\section{KESIMPULAN}

Desain pada kaus merupakan salah satu bentuk desain komunikasi visual. Desain pada kaus mengandung unsur elemen desain grafis yang terdiri dari gambar (ilustrasi), tipografi, warna, dan layout yang berfungsi sebagai media komunikasi visual. Unsur elemen tersebut merupakan hal penting dalam sebuah karya desain. Pada penelitian ini setelah melakukan observasi tiga desain kaus khas Tegal serta analisis pada ilustrasi, tipografi, warna, dan layout diperoleh kesimpulan sebagai berikut:

a. Warna yang banyak digunakan pada desain kaus khas Tegal adalah warna-warna 'netral' seperti warna hitam dan putih, dan juga warna 'cerah' seperti merah, oranye, kuning, hijau, dan biru. Warna bahan kaus juga menentukan warna desain/ilustrasi yang sudah dibuat.

b. Sebagian besar penggunaan huruf pada desain kaus-kaus tersebut sudah sesuai dengan teori tipografi dan memiliki tingkat keterbacaan yang tinggi sehingga teks dapat dengan mudah terbaca.

c. Pada desain merek Kaus "Tegal" lebih banyak menggunakan huruf-huruf berjenis sans serif dan serif. Sedangkan pada merek kaus "Galgil" huruf yang digunakan lebih beragam dan variatif. Sementara pada merek kaus "Kepriben" lebih banyak menggunakan huruf berjenis script dan sans serif. Selain itu, tipografi di beberapa desain kaus "Kepriben" sering menggunakan efek warp (melengkung atau bergelombang).

d. Ilustrasi pada desain kaus-kaus tersebut sudah dapat menunjukkan kekhasan Tegal dengan menampilkan ikon-ikon ciri khas Tegal seperti landmark dan juga kuliner khas Tegal. 
e. Sebagian tata letak dan susunan elemen-elemen desain kaus-kaus tersebut sudah cukup baik dan sesuai dengan prinsip dasar layout.

f. Ciri khas yang paling terlihat dari desain-desain kaus khas Tegal yaitu dari penggunaan bahasanya yang menggunakan bahasa Tegal. Mayoritas konsep desain kaus khas Tegal juga lebih menonjolkan kata-kata serta istilah berbahasa Tegal sehingga desain-desainnya lebih menonjolkan tipografi dan minim penggunaan ilustrasi.

\section{PENGHARGAAN}

Puji syukur kami panjatkan kepada Allah SWT dengan segala kemurahan, kemudahan dan karunia-Nya penelitian ini dapat diselesaikan. Terima kasih yang sebesar-besarnya kami ucapkan pada narasumber utama penelitian yang merupakan desainer kaus khas Tegal, yaitu: Afzalu Syahrudin (kaus "Tegal"), Indrawan Prasetyo (kaus "Galgil"), dan Apit (kaus "Kepriben"). Kami juga mengucapkan terimakasih pada rekan-rekan civitas akademika DKV STSRD VISI Yogyakarta serta redaksi jurnal Andharupa UDINUS yang telah memberikan kesempatan publikasi artikel jurnal ilmiah.

\section{DAFTAR PUSTAKA}

Anggraini, Lia \& Nathalia, Kirana. 2016. Desain Komunikasi Visual; Dasar Panduan untuk Pemula .Jakarta: Nuansa Cendekia

Darmaprawira, Sulasmi. 2002. Warna: Teori dan Kreativitas Penggunaannya. Bandung: ITB.

Info Tegal. Sejarah Lain dari Mardiyah di Tegal. Dalam http://infotegal.com/2016/02/sejarah-lain-dari-mardiyah-di-tegal/. (Diakses 19 Mei 2017)

Isnandar, A. R., \& Wantoro, W. 2016. Analisis Tipografi pada Logotype Band Forgotten. ANDHARUPA, 2(2), 121-136.

Jumanta. 2004. Kaus: Media Ekspresi Diri di Atas Dada. Jakarta: Puspa Swara.

Maharsi, Indria. 2013. TIPOGRAFI (Tiap Huruf Memiliki Nyawa dan Arti). Yogyakarta: CAPS (Center for Academic Publishing Service)

Mulyawan, M. Budi. 2012. Difusi Spasial Kaus Kedaerahan Galgil di Tegal dan Sekitarnya. Skripsi pada Universitas Indonesia Depok.

Mulyawan, M. Budi. Kaus Tegal dan Perjalanan Skripsi. Dalam https://budiografi.wordpress.com/2012/01/12/kaus-tegal-dan-perjalananskripsi/. (Diakses 27 November 2016)

Perkembangan Kaus di Indonesia. Dalam https://medium.com/@santaisaja/perkembangan-kaus-di-indonesiaa0d9ed9c4fce. (Diakses 5 Agustus 2017)

Redaksi Bisnis UKM. Merintis Bisnis Keluarga untuk Membahagiakan Orang Tua. Dalam http://bisnisukm.com/merintis-bisnis-keluarga-untuk-membahagiakan-orangtua.html. (Diakses 19 Mei 2017)

Rustan, Surianto. 2010. Layout: Dasar dan Penerapannya. Jakarta: Gramedia Pustaka Utama.

Rustan, Surianto. 2011. Huruf Huruf Tipografi. Jakarta: Gramedia Pustaka Utama. 
Sarwono, Jonathan., dan Hary Lubis. 2007. Metode Riset untuk Desain Komunikasi Visual. Yogyakarta: Penerbit Andi.

Setiawan, Ferry Rangga. 2015. Dagadu Djokja: Dari Kaki Lima Menjadi Retail 19942004. (Skripsi). Program Studi Sejarah, Fakultas Sastra Universitas Sanata Dharma Yogyakarta

Setiawan, A. 2016. Pencapaian Sense of Design dalam Perancangan Desain Komunikasi Visual. ANDHARUPA, 2(2), 207-217.

Sihombing, Danton. 2015. Tipografi dalam Desain Grafis. Jakarta: Gramedia Pustaka Utama.

Supriyono, Rakhmat. 2010. Desain Komunikasi Visual Teori dan Aplikasi. Yogyakarta: Penerbit Andi.

Website resmi Kaus Galgil. http://kausgalgil.id/profil-usaha/. (Diakses 16 Oktober 2016)

Website resmi Kaus Kepriben. http://www.kaus-kepriben.com/about-us. (Diakses 16 Oktober 2016)

Website resmi Kaus Tegal. http://www.kaustegal.com. (Diakses 16 Oktober 2016) 